Annals of Tropical Research 31[1]:102-112(2009)

(c) VSU, Leyte, Philippines

\title{
Morphological characterization of selected papaya (Carica papaya L.) inbreds and hybrids
}

\author{
Florence Lasalita-Zapico ${ }^{1}$ and Violeta N. Villegas ${ }^{2}$ \\ ${ }^{1}$ Science Department, College of Natural Sciences and Mathematics, \\ Mindanao State University, Fatima, General Santos City 9500; \\ ${ }^{2}$ Institute of Plant Breeding, College of Agriculture, University of the Philippines, \\ Los Baños, Laguna, Philippines
}

\begin{abstract}
Morphological analysis was undertaken to assess the degree of genetic relatedness and to characterize selected papaya (Carica papaya L.) inbreds and hybrids. Transmission of phenotypic traits from inbred parents to hybrid progeny followed the Mendelian pattern (complete dominance). The clustering mechanism separated the papaya genotypes into two groups. It was also revealed that some inbred lines presumably of very diverse origins exhibited similar morphological characteristics, raising the possibility that they have phylogenetic affinities and/or common origins. Screening for morphological traits with a high degree of polymorphism and with invariable expressions of the phenotypes would help in the identification of markers for hybrid identification and also in the accurate estimation of genetic relatedness among these hybrids and their parents.
\end{abstract}

Keywords: Carica papaya, morphological characterization, cluster analysis

Correspondence: F. L. Zapico Address: Science Department, College of Natural Sciences and Mathematics, Mindanao State University, Fatima, General Santos City 9500. E-mail: florence_zapico@yahoo.com; and florence.zapico@gmail.com.

DOI: $10.32945 /$ atr3116.2009 


\section{INTRODUCTION}

Papaya, a small semi-woody tropical fruit tree with melon-like fruits, is the best known member of the family Caricaceae and genus Carica (Sharon et al., 1992). Of the four members of the family, Carica is the only one which is of world wide economic importance (Manshardt and Drew, 1998).

Intraspecific F1 hybrids are obtained by crossing inbred parental lines. At the Institute of Plant Breeding, University of the Philippines at Los Banos, Laguna, papaya breeding efforts are centered on the development of varieties tolerant to the papaya ringspot virus ( PRSV). One example is the PRSV-tolerant variety called Sinta, which is a cross between Lines 5648 (female parent) and 4172 (male parent). Sinta yields well despite PRSV infestation and produces fruits with good eating quality.

Morphological data can be used to assess the hybridity of Carica intraspecific hybrids. In 1991, Chen and his collaborators (Chen et al., 1991) undertook the analysis of morphological characters of putative Carica papaya intraspecific hybrids. Characters of the hybrids found to be intermediate between both parents were the size, shape and color of the petals and ovary.

This study was undertaken to determine patterns of relationships in inbred lines from different geographic origins and their intraspecific hybrids using morphometric markers and their differential reactions to PRSV. Hybrid testing was also done to ascertain the mode of inheritance of the morphological traits under study. Information derived from this study could aid in the formulation of appropriate strategies and in making correct decisions for the papaya-breeding program of the IPB.

\section{MATERIALS AND METHODS}

\section{Morphological analysis}

Secondary data on the morphological characterization and reaction to PRSV of the papaya inbreds and hybrids were obtained from the Fruit and Ornamental Crops Division of the Institute of Plant Breeding, UP- 
Los Banos. Twenty intraspecific hybrids and also twenty each of their inbred parents were examined for the following morphological characters derived from the papaya descriptor list published by IPGRI in 1988:

1. Flesh color

2. Petiole color

3. Height and first flower

4. Fruit size

5. Total soluble solids

6. Stem diameter

7. Flesh thickness

8. \% Edible portion

Screening for PRSV tolerance

The papaya hybrids and inbreds were made to grow in certified PRSV-positive fields alongside infected papaya plants and were closely monitored for development of viral symptoms. Screening for reaction to PRSV was done through visual evaluation of the severity of symptoms based on the disease rating scale used by Magdalita et al(1997) and Cook (1972). Among these symptoms were ringspots on fruits, water-soaked lesions on petioles and stems and chlorosis in the leaves. Mottling and chlorosis of the youngest leaves are sure signs of systemic viral infection. Elongated, dark green streaks initially develop on petioles and upper half of the stem and eventually spread out to the entire trunk during advanced stages of infection. Infected plants are also characterized by reduced fruit set. Papaya plants which showed slight to moderate disease symptoms and which produced 15-20 fruits during their entire fruiting period were categorized as tolerant. Inversely, those in the advanced stages of infection (especially if the lesions appeared along the length of the trunk) and which bore less than 15 fruits during the entire fruiting period were classified as susceptible ( Magdalita and Mercado 1997). 


\section{Data analysis}

Computations of quantitative morphological data were based on twenty (20) measurements for both hybrids and their inbred parents. The generated data was used as input for SIMINT (Similarity for Interval Data) program in the computation of a matrix of Euclidean distances. This distance matrix was subjected to cluster analysis using UPGMA (Unweighted Pair-Group Method, Arithmetic Average) of the SAHN (Sequential, Agglomerative, Hierarchal and Nested clustering methods) of NTSYS-pc to produce a dendogram depicting the genetic similarity of the genotypes under study( Rolhf, 2000).

\section{RESULTS AND DISCUSSION}

\section{Morphological characterization}

The Mendelian pattern of inheritance (Complete Dominance) was very apparent for the qualitative traits evaluated. Yellow flesh and purple petiole are dominant to red flesh and green petioles respectively. Crossing of inbred lines 4172, 3878 and 5893 (all with red flesh color) with yellowfleshed 5648 resulted in hybrids having yellow flesh color as expected (Figures 1 and 2). In terms of petiole color, only inbred line 5893 had the dominant trait (purple petiole). Crosses involving 5893 with the Lines 5648 and 4172 yielded hybrid offspring with purple petioles (Table 2).

Table 2 also shows the data obtained from morphological characterization involving quantitative traits. The Solo parent exhibited highest vales for stem diameter and plant height. It was also observed that Lines 5648 and Solo had the smallest fruits as contrasted to the other three inbreds. These two lines also exhibited nearly similar \% edible portion values.

\section{Screening for PRSV tolerance}

Tolerance to PRSV was observed to be dominant to susceptibility to the virus. At IPB, the strategy for breeding for PRSV tolerance involved 


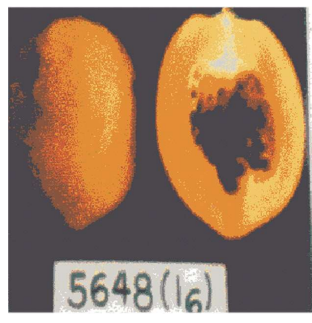

A

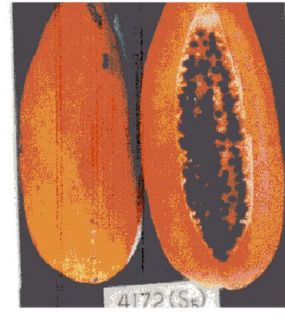

$\mathrm{B}$

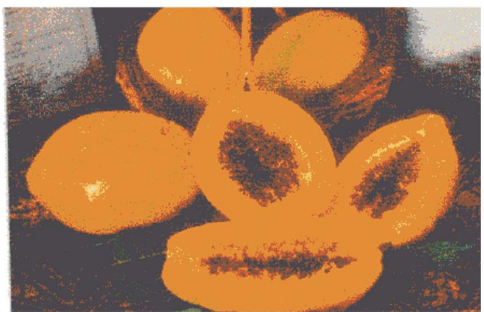

$\mathrm{C}$

Figure 1. Inbred Lines 5648 (A) and 4172 (B) and their hybrid progeny, Sinta ( C)

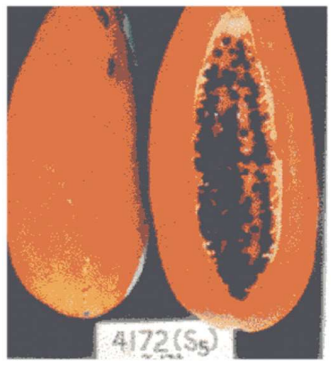

A

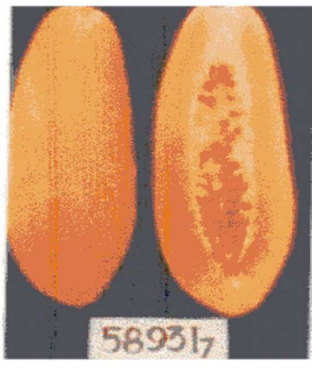

B

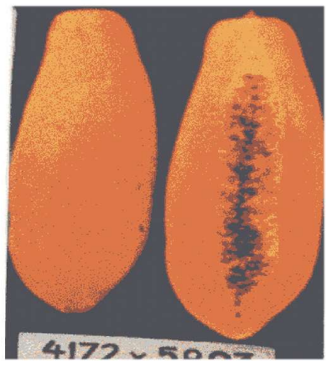

$\mathrm{C}$

Figure 2. Inbred Lines 4172 (A) and 5893 (B) and their hybrid progeny, Giliw ( C) 
Table 1. List of Inbred parents and intraspecific hybrids evaluated

\begin{tabular}{ll}
\hline \multicolumn{1}{c}{ Inbred Parents } & \multicolumn{1}{c}{ Intraspecific Hybrids } \\
\hline Inbred parent 5648 (Florida) & Hybrid Sinta $(5648 \times 4172)$ \\
Inbred parent 4172 (Cavite) & Hybrid Giliw $(4172 \times 5893)$ \\
Inbred parent 5893 (Taiwan) & Hybrid A $(5648 \times 5893)$ \\
Inbred parent Solo (Hawaii) & Hybrid B $(5648 \times$ Solo $)$ \\
Inbred parent 3878 (Cagayan de Oro) & Hybrid C (5648 x 3878) \\
\hline
\end{tabular}

crossing of PRSV-susceptible lines with tolerant lines to confer tolerance to the former. This had been successfully done with $5648 \mathrm{x}$ Solo ( Hybrid B) and 5648 x 3878 (Hybrid C) crosses where the susceptible Solo and 3878 lines were used as parental inbreds together with the tolerant inbred 5648 as the other parent (Table 2). Hybrids tolerant to the virus were produced. Crosses involving 5648 and the tolerant varieties 4172 and 5893 also yielded tolerant hybrids (Sinta and Hybrid A) as expected.

\section{Cluster analysis}

Cluster analysis done on both qualitative and quantitative data divided the hybrids and inbreds into two distinct groups with inbred lines 5648, Solo and their hybrid, B, making up the first group and the remaining members, the other (Figure 3). Papaya genotypes making up this first group had the smallest fruit sizes, yellow flesh color, green petioles and exhibited almost similar \% edible portions. The resulting dendrogram also shows the divergence of inbred parents 5648, Solo and their hybrid $\mathrm{B}$ at about 180 Euclidean distance units suggesting their relatively distant relationship from the other papaya genotypes and their close relationship with each other. This morphological proximity between 5648 and Solo seems to bear out the assumption that they have common geographic/ phylogenetic origins. Solo papaya germplasm from the Hawaiian Islands could have been introduced to Florida during expansion of the breeding program. This introduction of the Solo germplasm to the US mainland therefore, maybe responsible for the remarkably similar appearances with 5648 which are apparent even under visual examination (Wasee et al 1980; Conover and Litz 1978; Davis et al 2003; Gonzalves 2004) . 


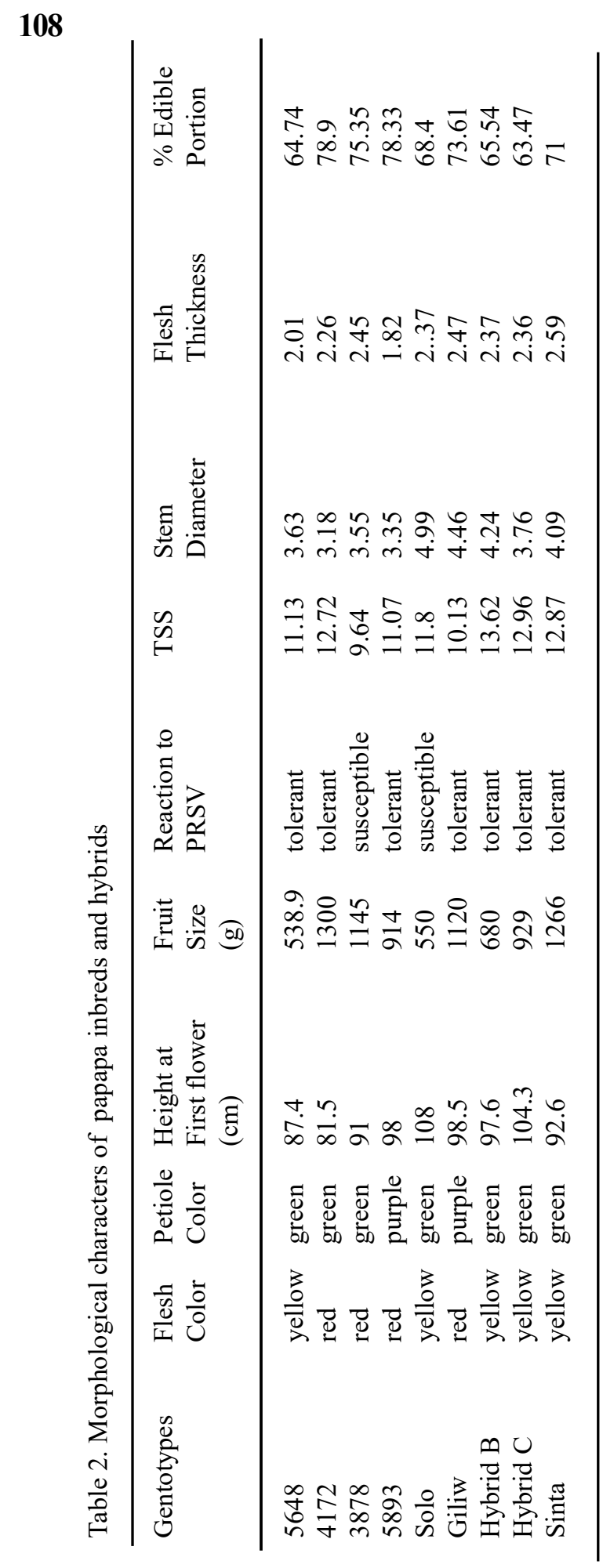

Zapico and Villegas 


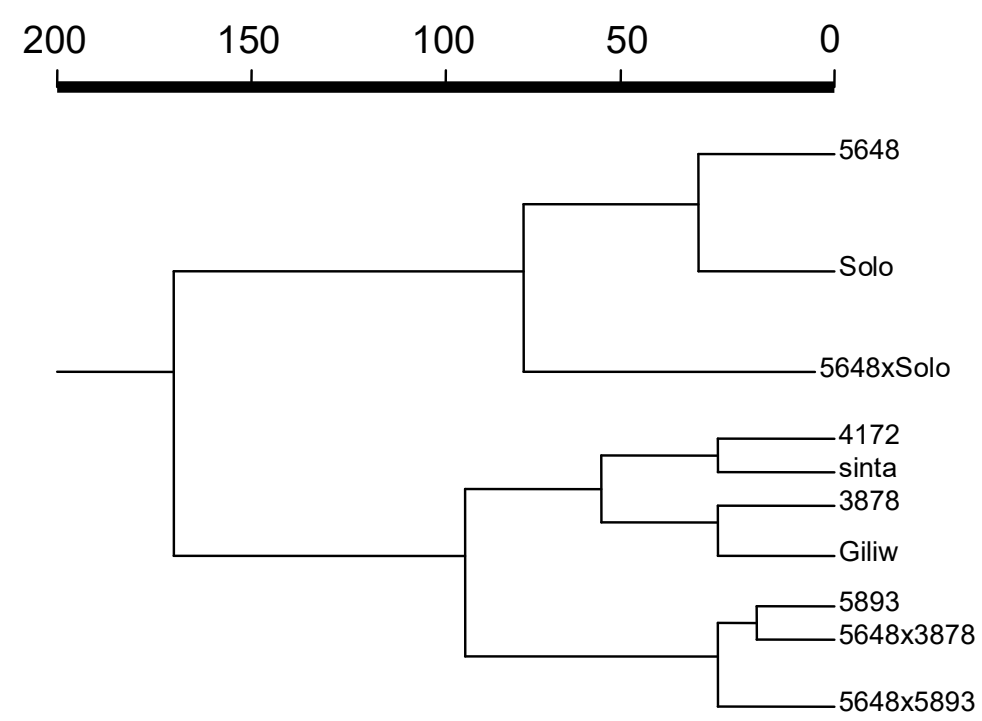

Figure 3. UPGMA Dendogram showing the relationships among the papaya inbreds and hybrids as revealed from morphological data. 
One unexpected outcome was the affinity between Giliw (4172 x 5893 ) and 3878 since they had no common parent. One possible explanation is that 4172 and 3878 could actually be related. Inbred 4172 is a Cavite strain while inbred 3878 is from Cagayan de Oro. However, 3878 could have been brought from Cavite to Cagayan de Oro in the past when the processing plant for tropical fruit cocktail was established by a big company (Personal Communication with Dr. Violeta Villegas). Collected data revealed that these two inbred lines had similar morphological features except for their differential reactions to PRSV. Line 4172 is tolerant to the virus while Line 3878 is susceptible. These differential responses to PRSV could be explained by the fact that Line 3878 is from an area (Cagayan de Oro) which is PRSV-free. Line 4172 is from Cavite where disease pressure is very high and as such, this inbred line could have developed tolerance to PRSV in response to this selective pressure.

The study also revealed low intraspecific diversity for the Carica papaya L. genotypes studied which could possibly be due to natural and human selection for PRSV tolerance and the dispersal of the papaya germplasm through human migration. These findings about the low genetic diversity of cultivated papaya are consistent with those arrived at by Stiles et al (1993), Van Droogenbroeck (2002), Carrasco et al (2008) and d' Eeckenbrugge et al., 2005) using RAPD, AFLP, ISSR and morphological/ isozyme markers respectively. These researchers found out that despite very diverse origins and their relative isolation, the different papaya cultivars tested were genetically uniform. Kim et al (2002) further added that this narrow genetic diversity is a consequence of inbreeding from a limited genepool. Another probable explanation was proposed by Ocampo et al (2006) based on his findings in Guadaloupe in the French West Indies. Due to severe bacterial infestation, only a few isolated papaya populations stands were able to escape the disease. These small populations were left to interbreed resulting in low genetic diversity in the present-day papaya populations in the area. A similar bottlenecking event could have taken place in the early 1980s when the thriving papaya industry in the Philippines was brought to the brink of collapse due to widespread PRSV infestation. Most of the papaya plants died and only a 
few hardy strains which bore tolerance genes to the virus survived. Human selection for these tolerant strains could be the agent responsible for the narrow genetic base of the crop. Or it is also possible that with the small populations of surviving stands left to interbreed, genetic drift took place, resulting in genetic uniformity.

This study was hampered by the paucity of suitable morphological markers. For the future, it would be interesting to carry out the screening of more morphological markers for a more accurate estimation of genetic relatedness. It is also recommended that this study will be expanded to include a bigger number of papaya inbreds and hybrids to have a true picture of genetic diversity in the species. A last consideration is the susceptibility of morphological characters to environmental/ developmental variations. Papaya is especially sensitive to environmental fluctuations as nutrient deficiency, light and waterlogging and manifests effects of these factors through altered morphology. The influence of factors external to the plant's genotype is very much apparent when morphological traits are used. It is suggested then only those phenotypic characters that have invariable expressions of the phenotypes and subjacent environmental alterations must be used. This way, Ortiz (1997) stressed, bias can be avoided and a reliable and accurate measure of variability can be generated.

\section{LITERATURE CITED}

CARrasco, B., P. AVILA, P. PEREZ-DIAZ, P. MUNOZ, R.GARCIA, B. LAVANDERO, A. ZURITA-SILVA, J. RETAMALES, and P. CALIGARI. 2008. Genetic structure of highland papayas (Vasconcellea pubescens (Lenne et C. Koch) Badillo ) cultivated along a geographic gradient in Chile as revealed by Inter Simple Sequence Repeats (ISSR). Genet Resour Crop Evol.

CHEN, M. H., C.C. CHEN, D. N. WANG and F. C. CHEN. 1991. Somatic embryogenesis and plant regeneration from immature embryos of $C$. papaya and $C$. cauliflora cultured in vitro. Can. J. Bot. 69: 1913-1918.

CONOVER, R.A., and R. E. LITZ. 1978. Progress in breeding papayas with tolerance to papaya ringspot virus. Proc. Fla. State Hort. Soc. 91: 182-184.

COOK, A. A. 1972. Virus disease of papaya. Technical Bulletin (Florida Agicultural Experiment Station) no. 750 . 
DAVIS, M.J. , T. L. WHITE and J. H. CRANE. 2003. Papaya variety development in Florida. Proc. Fla. State Hort. Soc. 116: 4-6.

D' EECKENBRUGGe, G. C., M. T. RESTREPO, D. R. JIMENEZ, and E. MORA. 2005. Morphological and Isozyme Characterization of common papaya in Costa Rica. Chan Y.K., Paull Robert E. (ed.), Shukor A.R.Abd. (ed.). Proceedings of the first International Symposium on Papaya. Genting Highlands, Malaysia, November 22 - 24, 2005. Louvain : ISHS [Belgique], p. 109-120. International Symposium on Papaya. 1, 2005-11-22/2005-11-24, Genting Highlands, Malaisie.

GONZALVES, D. 2004. Transgenics papaya in Hawaii and beyond. AgBioForum 7(1\&2): 36-40.

KIM, M. S., P. H. MOORE, F. ZEE, M. M. FITCH, R. M. STEIGER, R. M. MANSHARDT, R. E. PAULLI, R. A.DREW, T. SEKIOKA, and R. MING. 2002. Genetic Diversity of Carica papaya as revealed by AFLP markers. Genome 45: 503-512

MAGDALITA, P. M., D. M. PESLEY, I. D. GODWIN, R.A. DREW, and S. W. ADKINS (1997). Screening C. papaya x C. cauliflora hybrids for resistance to PRSVtype P. Plant Path. 46:837-841.

MANSHARDT, R. and R. DREW. (1998). Biotechnology of Papaya. Proc. of Int. Symposium in Biotechnology. Acta. Hortic. 461: 65-73.

OCAMPO, D., G. C.EECKENBRUGGE, S. BRUYERE, L. DE BELLAIRE, and P. OLLITRAUT. 2006. Organization of morphological and genetic diversity of Caribbean and Venezuelan papaya germplasm. Fruits 61 (1): 25-37

ORTIZ, R.(1997). Morphological variation in Musa germplasm. Genet Resour Crop Evol. 4: 393-404.

SHARON, D., J. HILLEL, A. VAINSTEIN and U. LAVI. (1992) Application of DNA fingerprints for identification and genetic analysis of Carica papaya and other Carica species. Euphyt. 62: 119-126

STILES, J.I., C. LEMME, S. SONDUR, M. B. MORSHIDI and R. MANSHARDT . (1993). New challenges confronting plant breeders in isozymes in plant genetics and breeding. Part A. SD Tanksley and TJ Orton (eds). Publishers BV, Amsterdam. Pp. 443-468.

WASEE, S., S. SUBHADRABANDHU , and B. SILAYOI ( 1980). Studies on certain characteristics of four papaya ( Carica papaya L.) varieties. Kasetsart Journal: Natural Science ( 014: 1): 19-25. 